\title{
Öğrencilere Bilgi Okuryazarlığı Becerilerinin Kazandırılmasının Önemi ve Okul Kütüphanecilerinin Bu Alandaki Rolü
}

\author{
The Importance of Teaching Information Literacy
}

Skills to Students and the Role of School Media Specialists on this Issue

\section{S. Serap Kurbanoğlu*}

$\ddot{\mathbf{O z}}$

Bilgi toplumlan, yaşam boyu ögrenme becerilerine sahip bireylere gereksinim duymaktadır. Bilgiye ulaşma ve bilgiyi kullanma becerisi olarak tanımlanan bilgi okuryazarlığı yaşam boyu ögrenmenin temelini oluşturur. Bu durum bilgi toplumunun bireyleri için bilgi okuryazarliğı eğitim programlarınin önemini artırmaktadir. Bu makalenin amacı, bilgi okuryazarlığı becerilerinin ilk ve ortaögretimde kazandırımasını önemini vurgulamak, öğrenciler için hazırlanacak bir bilgi okuryazarliğı programının içeriğini tartısmak, bu programların hazırlanmasında okul kütüphanecilerinin rolünü ve ögretmenlerle işbirliğinin önemini vurgulamaktır.

Anahtar sözcükler: Bilgi okuryazarlığ, Bilgi okuryazarhğı eğitimi, Bilgi okuryazarliğı standartlanı, Bilgi okuryazarlığı - okullar, Okul kütüphanecileri.

\begin{abstract}
An information society needs individuals who have lifelong learning skills. Information literacy, the ability to find and use information, is the keystone of lifelong learning. This increases the importance of information literacy programs for the individuals of information society. The aim of this paper is to point out the importance of teaching information literacy skills at primary and secondary schools, to discuss the content of an information literacy program for students and to stress the role of school media specialists on preparation of these programs in cooperation with teachers.
\end{abstract}

\footnotetext{
- Doç. Dr.; Hacettepe Üniversiłesi Kütüphanecilik Bölümü öğretim üyesi (serap@hacettepe.edu.tr)
} 
Keywords: Information literacy, Information literacy education, Information literacy standards, Information literacy - schools, School media specialists.

\section{Giriş}

Değişikliği simgeleyen bir geleceğe hazırlıklı olabilmeleri için çağımız bireylerinin, problem çözebilen, bilgiye erişebilen, bilgiyi yönetebilen ve iletişim kurabilen bireyler olarak yetişmeleri gereklidir.

Içinde bulunduğumuz çağda başarılı olabilmek için çağın bireyleri, büyük miktarlarda artan ve farklı ortamlarda kayıtlı bulunan bilginin becerikli tüketicileri haline gelmek durumundadır. Format açısından geleneksel olarak adlandırabileceğimiz basılı bilgi kaynaklarına binlerce elektronik kaynağın ve milyonlarca web sitesinin eklendiği bir çağda etkin bir bilgi tüketici ve buna bağlı olarak bir bilgi üreticisi olmak giderek güçleşmektedir.

Üretilen bilgi miktarındaki artışın yanı sıra bilim ve teknoloji alanındaki gelişmeler ve küreselleşme ile birtikte yaşanan değişiklikler günümüz bireylerini bir yandan sayısız fırsatlarla karşı karşıya bırakırken diğer taraftan gereksinim duyacakları bilgi ve becerilerde değişikliklere neden olmuştur. Günümüz toplumlarının gereksinim duyduğu insan profili, geçmişte gereksinim duyulan insan profilinden farklılık göstermeye başlamıştır.

Amerika Birleşik Devletleri'nde yapılan bir çalışmada 21. yüzyılın bireylerinin başarılı bir iş performansı göstermeleri için etkin olmaları gereken alanlar şu şekilde belirlenmiştir (SCANS, 1991):

- Kaynak kullanımı (zaman, para, mekan, materyal ve insan gücü yönetimi).

- Kişilerarası ilişkiler (grup çalışması, iletişim kurma, bilgiyi paylaşma).

- Bilgi kullanımı (bilgiye ulaşma, bilgiyi değerlendirme, düzenleme, yorumlama ve iletme).

- Teknoloji kullanımı (her tür teknolojiden yararlanabilme, uygun teknolojinin seçimi, teknolojik sorunları çözme). 
- Sistem analizi (toplumsal, örgütsel ve teknik sistemlerin nasıl çalıştığı$\mathrm{n} ı$ anlama, bu sistemleri yönetebilme, sistem tasarımı ve bakımı).

Söz konusu alanlarda etkinlik gösterebilmek için gerekli temel beceriler ve özellikler ise şu şekilde sıralanmıştır (SCANS, 1991):

- Temel beceriler: Okuma-yazma, aritmetik, konuşma ve dinleme becerileri.

- Düşünme becerileri: Akıl yürütme, karar verme, problem çözme, yaratıcilık.

- Kişisel özellikler: Sorumluluk alabilme, diğer kişi ve gruplarla iletişim kurabilme, kendini yönetebilme, özgüven.

TÜSIAD (1999, s. 35) tarafından hazırlanan bir raporda da, bir ülkenin kalkınmışlık düzeyini belirlemede kullanılan en önemli ölçütterden birinin, o ülkenin sahip olduğu insan kaynaklarının niteliği olduğu vurgulanmakta ve çağımız bireylerinde bulunması gereken temel beceriler şu şekilde belirtilmektedir: Illetişim kurma, uyum sağlama, doğru bilgiye ulaşma, karar verme, sorumluluk alma, yaratıcılık gösterme, işbirliği yapma, sorun çözme, karmaşık sistemleri algılama ve kendini geliştirme.

21. yüzyıl toplumları için öğrenmeyi öğrenmek önem kazanmıştır. Bilgi toplumları artık, yaşam boyu öğrenme becerilerine sahip bireylere ihtiyaç duymaktadır. Yeni bir kavram olan "learning community" (öğrenen toplum) sürekli değişen bilgi intiyaçlarını karşılamak için günümüz bireylerinin yaşam boyu sürecek bir araştırmanın içinde olduklarını vurgulamaktadır (AASL/AECT, 1998, s. 2). Artık yaşam boyu değişmeden süren meslek kalmamıştır. Bu nedenle, bireyleri yetiştirirken onların çağdaş gelişmeieri yakından izleyerek, kendi yaşamlarında gerekli uyarlamaları yapabilmelerini kolaylaşııracak bilgi, tutum ve becerilerle donatılmaları gerekmektedir. Tüm çalışma alanları için geçerli olan bu yeterliklere sahip oimayan bireylerin bilgi toplumunun gereklerini yerine getirebilmeleri olanaklı değildir (TÜSIAD, 1999, s. 35). Kısacası, bilgi çağında yetişen her bireyin öğrenmeyi öğrenme temel becerisini kazanmış olması beklenmektedir.

Sonuçta, bilgi toplumunun bireylerinde, bir başka deyişle bilgi toplumunun gereksinim duyduğu insan gücünde bulunması gereken becerilerin arasında 
bilgi ile ilgiti becerilerin (bilginin bulunması, değerlendirilmesi, kullanılması, üretilmesi ve iletilmesi gibi) mutlaka bulunması gerektiği görülmektedir. Bilgi ile ilgili becerilerden söz edildiğindeyse "bilgi okuryazarlığı" kavramı ortaya çıkmaktadır.

\section{Bifgi Okuryazarlığı}

Bilgi okuryazarığının pek çok tanımına rastłamak olasıdır. Çoğu eğitimciler ve kütüphaneciler tarafından yapılan bu tanımlar genelde birbirlerine benzerler.

Bilgi okuryazarlığı, kısaca, bilgiye ulaşma ve bilgiyi kullanma becerisi olarak tanımlanmaktadır (AASL/AECT, 1998, s. 1). Bilgi okuryazarı olmak, bilgiye ihtiyaç duyulduğunda bunu hissetmek, ihtiyaç duyulan bilgiye ulaşmak, elde edilen bilgiyi değerlendirmek ve etkin olarak kullanmaktır (ALA, 1989).

Bilgi okuryazarları, bilginin nasıl düzenlendiğini, almaları gereken kararlar ve yaptıkları işler için gereksinim duydukları bilgiyi nasıl bulacaklarını ve nasıl kullanacaklarını, dolayısıyla nasıl öğreneceklerini bilirler. Bir başka deyişle bilgi okuryazarları, yaşam boyu öğrenime hazırlanmış kişilerdir (ALA, 2000).

Bilgi okuryazarlığı terimi, bilgi problemlerini çözme (information problemsolving) becerisi olarak da tanımlanmaktadır (ALA, 2000).

\section{İlk ve Ortaöğretimde Bilgi Okuryazarlığı Eğitiminin Önemi}

Çağın intiyaç duyduğu nitelikli insan gücünün yetiştirilmesi eğitim sisteminin görevidir. Özellikle ortaöğretim düzeyinde uygulanan eğitim programları bu açıdan büyük değer taşımakta, birçok ülkede geçmiştekinden farklı bir insan tipi yetiştirme yüküm!ülüğü ile karşı karşıya kalan eğitim kurumları yeniden yapılanma çalışmaları yürütmektedir (TÜSIAD, 1999, s. 19-20). Sonuçta geleceğe yapılacak en önemli yatırım, eğitim sistemlerine işlevsellik kazandırıması ve/veya yeniden düzenlenmesidir (Bilişim, 2001, s. 25).

Okulların yeniden yapılandırılması çalışmaları bilgi okuryazarlığı ile doğrudan olarak ilintilidir. Okulların yeniden yapılanması öğretmenlerin rollerini 
değiştirirken, öğrenciler de çeşitli kaynaklardan elde ettikleri bilgiyle etkileşim sonucunda öğrenen aktif katılımcılar haline gelmektedir. Çeşitli biłgi kaynaklarının kullanımı sonucu oluşan öğrenim genellikle kaynağa dayalı öğrenim (resource-based learning) olarak adlandırımaktadır (AASLAECT, 1998, s. 2; ALA, 2000; ayrıca bakınız: Spitzer, Eisenberg ve Lowe, 1998, s. 132; Gürdal, 2000, s. 181-184). Kaynağa dayalı öğrenim her formattaki bilginin öğrenciler tarafından etkin şekilde kullanımını gerektirir. Burada bilgi okuryazarlığı becerileri, öğrencilerin sahip olmaları gereken temel becerilerden birisi olarak karşımıza çıkmaktadır. Öğrencilerin bu becerilere sahip olabilmesinin tek yolu ise bu alanda gerekli eğitimin kendilerine verilmesidir.

ABD'de bir eğitim derneği olan ASCD (the Association of Supervision and Curriculum Developments), bilgi okuryazarlığı eğitiminin, her öğrencinin eğitim sürecinin bir parçası olması gerektiğini vurgulamakta ve her düzeyden eğitim kurumunu, öğrenciler için eğitim programları ile bütünleştirilmiş bilgi okuryazarlığı programları hazırlamaları konusunda teşvik etmektedir (ALA, 2000).

Ülkemizde de, VIII. Beş Yıllık Kalkınma Planı Bilişim Teknolojileri ve Politikaları Özel İhtisas Komisyonu'nun Bilgi Hizmetleri ve Içerik Alt Komisyonu tarafından hazırlanan raporda bilgi okuryazarlığı konusunda büyük eksiklerimiz olduğu, her tür eğitim kurumunda bilgi okuryazarlığı derslerinin verilmesinin ve okul kütüphanelerinin bilgi okuryazarlığını destekjeyecek şekilde yapılandırılmasının gerektiği belìtilerek konuya değinilmektedir (Bilişim, 2001, s. $28,43,45)$. Ülkemizde zorunlu eğitim kapsamına giren 8 yıllık ilköğretim dönemi, bilgi okuryazarlığı eğitimi açısından büyük öneme sahiptir. Zorunlu eğitim dönemini tamamlayan pek çok bireyin eğitimlerine devam etmedikleri, bir kısmının da ortaöğretimden sonra eğitim hayatlarının noktalandığı düşünüldüğünde bu bireylere çağın gerektirdiği bilgi okuryazarlığı becerilerini kazandırmak için en uygun fırsatın ilk ve ortaöğretim dönemleri olduğu ortaya çıkmaktadır. Bilgi okuryazarlığı becerilerini ilköğretim yılıarında kazanmaya ve geliştirmeye başlayan öğrencilerin gerek yükseköğretimde gerekse iş hayatında gösterecekleri başarı ve uyum kolaylığı da gözardı edilmemelidir.

Tüm bu nedenlerle başta ABD'de olmak üzere pek çok ülkede bilgi okuryazarhı̆ı becerilerinin, öğrencilere, ifk ve ortaöğretim dönemlerinde kazandı- 
rılmasına yönelik çalışmalar yapıldığı görülmektedir (örnekler için bakınız: Spitzer, Eisenberg ve Lowe, 1998, s. 148-179). Az sayıda olmakla birlikte ülkemizde de bu alanda yapılan bazı çalışmalar vardır. Örneğin, TED Ankara Koleji Vakfı Okullarında 1999 yılından itibaren 6. sınıf öğrencilerine yönetik bir bilgi okuryazarlığı programı yürütülmektedir. Özel Bilkent İlköğretim Okulunda, bir yüksek lisans çalışması kapsamında (Kavuncu, 2001), 20 öğrenciye yönelik kısa süreli bir çalışma yapılımıştır. Ankara ve İzmir Özel Tevtik Fikret Okullarında 2000-2001 öğretim yılında öğretmenlere yönelik bilgi okuryazarlığı seminerleri düzenlenmiştir.

Kalkınmak için gereksinim duyduğu insan gücünü yetiştirmek isteyen her ülkenin bilgi okuryazarlığı eğitimini olası en erken düzeyde eğitim programlarının içine alması gerekmektedir. İlk ve orta dereceli okullarda bilgi okuryazarlığı eğitiminin aşamalı olarak düzenlenmesi ve izlenmesi çok daha kolaydir.

\section{Bilgi Okuryazarlığının Aşamaları}

Bilgi okuryazarłığı, bilgi problemlerini çözme becerisi olarak da tanımlandığından, (ALA, 2000) bilgi problemi çözme aşamalarını bilgi okuryazarlığının aşamaları olarak ele almak olasıdır. Eisenberg tarafından "big six" (büyük altılı) olarak adlandırılan bilgi problemi çözme aşamalarının farklı kaynaklarda farklı sayıda fakat benzer başlıklar altında ele alındığı görülmektedir (Eisenberg ve Berkowitz, 1992, s. 28-29; Spitzer, Eisenberg ve Lowe, 1998, s. 155; lannuzzi, Mangrum II ve Strichart, 1999, s. 193-196; ALA, 2000; The Information, 2000). Söz konusu aşamaları aşağıdaki gibi özetlemek mümkündür:

1. Bilgi Ihtiyacının Tanımlanması: Bilgi problemi çözümünde ilk adım bir bilgi ihtiyacının varığının kabul edilmesi ve bu ihtiyacın tanımlanmasıdır. Bu aşamada bilgi okuryazarı öğrenci, bilgi problemini çeşitli sorgulama becerileri ile formüle edebilir; gereksinim duyduğu bilgiyi mevcut bilgisiyle ilişkilendirebilir.

2. Bilginin Aranması: Bilgi problemi formüle edildikten sonra bir arama/tarama planının geliştirilmesi zorunludur. Tarama stratejileri oluşturulur. Bu aşama, bilginin varlığından haberdar olma aşamasıdır. Öğrenci, bir 
seri ek soruyla ne tür bilgiye gereksinim duyduğuna karar verir; anahtar kelimeleri, kavramları, konu başlıklarını belirler; birden fazla bilgi kaynağı kullanmanın önemini bilir; potansiyel bilgi kaynaklarını belirler.

3. Bilginin / Bilgi Kaynaklarının Bulunması: Bu aşamada aranılan bilgi (gereksinim duyulan bilgiyi içeren bilgi kaynakları) bulunur ve elde edilir. Bilginin kaynak içinde bulunması da bu aşamada gerçekleşir. Öğrenci okul kütüphanesindeki katalogları ve bibliyografik kaynakları kullanarak konusuyla ilgili basıli, görsel işitsel ve elektronik kaynakları bulur; çevrimiçi veri tabanlarını kullanarak ve kütüphanelerarası ödünç verme yoluyla okul kütüphanesi dışındaki kaynakları bulur; ek bilgi kaynakları için yararlanabileceği diğer bilgi merkezlerini saptar ve kullanır; bilgi kaynağı olarak insanlara başvurur; bilgi kaynaklarının belirlenmesinde öğretmenleri ve okul kütüphanecileri ile bilgi alışverişi yapar; bilgi kaynaklarının içindeki bilgiye erişim için kaynakların içindeki indeksler, içindekiler tablosu, göndermeler gibi kaynak içi erişim araçlarını kullanır.

4. Bilginin / Bilgi Kaynaklarınn Kullaniması: Potansiyel olarak faydalı olacağı düşünülen bilginin (bilgi kaynaklarının), elde edildikten sonra gözden geçirilmesi ve değerlendirilmesi gerekir. Farklı kaynaklardan elde edilen bilgi birleştirilir, özümsenir, değerlendirilir. Kısaca, elde edilen bilgi, bilgi problemini çözmek için kullanılır. Öğrenci bu aşamada, bulduğu bilgi kaynaklarını bilgi gereksinimi açısından gözden geçirir; birincil ve ikincil kaynakları ayırır; bilginin güvenirliğine, güncelliğine karar verir; gerçeklerle görüşleri birbirinden ayırabilir; varsa mantık hatalarını yakalayabilir, eksikleri saptayabilir; bilgiyi sınıflandırabilir; kavramlar arasındaki ilişkileri kavrar; sebep ve sonucu birbirinden ayırır; kaynaklar arasındaki ortak noktaları ve fikir ayrılıklarını saptayabilir; kendi öğrenme sitiline en uygun formattakj bilgiyi seçer; gerekirse bilgi problemini yeniden gözden geçirir ve yeniden tanımlar; kendi ifadeleriyle bilgiyi özetler; yeni elde ettiği bilgiyi önceki bilgisiyle birleştirir; bilgiyi fark। bir şekilde yeniden düzenler; topladığı bilgiyi orijinal problemle karşılaştırır, gerekli durumlarda stratejilerini değiştirir, ek bilgi kaynakları bulur ve bilgiyi yeniden inceler; topladığı bilgiye dayanarak ve bu bilgiyi kendince yorumlayarak bir sonuca ulaşır. 
5. Bilginin lletimi: Bilgi problemi çözme gayretlerinin sonuçları düzenlenir ve bu sonuçlar çeşitli yollarla (sözlü veya yazılı olarak) başkalarına iletilir. Öğrenci, amacına ve bilgi ileteceği kitleye uygun bir iletim formatı (yazılı, sözel, görsel) seçer; sunumunu hazırlar; sunumda yararlandığı kaynaklara gerekli göndermeleri yapar.

6. Değerlendirme: Bilgi problemi çözme aşamaları ve ortaya çıkan ürün değerlendirilir. Ürünün bilgi probleminin çözümüne katkısına ve sonuca ulaşmak için atılan adımların ne kadar uygun ve etkin olduğuna karar verilir. Yapılan değerlendirmeden ileriye yönelik dersler çıkartılır. Öğrenci kendi çalışmalarını değerlendirebileceği gibi başkaları tarafından da değerlendirilebilir (sınıf arkadaşları, öğretmenler, kütüphaneciler, ebeveynler). Bu aşamada öğrenci, araştırma problemi, tarama stratejileri, kaynaklar veya yorumlar ne şekilde genişletilebilirdi, gözden geçirilebilirdi veya değiştirilebilirdi sorularına yanıt arar; süreci yeniden değerlendirir ve kendisini geliştirmek için gerekli olan şeyleri belirlemeye çalışır.

\section{Öğrenciler İçin Bilgi Okuryazarlığı Standartları}

Illk ve ortaöğretim düzeyindeki öğrenciler için bilgi okuryazarlığı standartları AASL (American Association of School Librarians) ve AECT (Association for Educational Communications and Technology) tarafından geliştirilmiştir. Söz konusu standartlar, üç genel kategoride ele alınmaktadır. İlk kategori (ilk üç standart), temel bilgi okuryazarlığı standartlarını içermektedir. İkinci kategorì, bağımsız öğrenme (kendi kendine öğrenme) ve son kategori de sosyal sorumluluklar ile ilgili standartlardan oluşmaktadır. Söz konusu standartları şu şekilde listelemek mümkündür (AASL/AECT, 1998, s. 8-9):

Bilgi okuryazarlığı temel standartiarı:

Bilgi okuryazarı bir öğrenci;

1. bilgiye etkin şekilde ulaşır,

* ACRL tarafindan yükseköğretim için geliştirimiş standarlar da vardir. Standantlarn büyük ölçüde örtüşü̈gü görülmektedir. Bakıniz: ACAL, 2000. Türkçesi için aynca bakinz: Yaivaç; 2001, s. 146-148. 
2. bilgiyi eleştirel olarak değerlendirir.

3. bilgiyi doğru ve yaratıcı şekilde kullanır.

Bağımsız (kendi kendine) öğrenme standartları:

Bağımsız öğrenebilen öğrenci bilgi okuryazarıdır ve;

4. ilgi alanlarına yönelik bilgiyi takip eder,

5. her formattaki bilgiye ilgi duyar,

6. bilgi arama ve üretme aşamalarında mükemmelliğe gayret eder.

Sosyal sorumluluk standartları:

Öğrenen topluma pozitif katkı sağlayan öğrenci bilgi okuryazarıdır ve;

7. demokratik bir toplum için bilginin öneminin farkındadır,

8. bilgi ve bilgi teknolojisi konularında etik davranışlar sergiler,

9. bilgi üretimine katkıda bulunmak için başkalarıyla işbirliği yapar.

Bu üç kategori toplam 9 standart ve 29 göstergeden oluşmaktadır. Her standart için göstergeler belirlenmiştir (AASL/AECT, 1998, s. 9-41):

Temel Standartlar

Standart 1: Bilgi okuryazan öğrenci, bilgive etkin şekilde ulaşır: Bilgi okuryazarı ne zaman bilgi araması gerektiğini, kendisini uygun bilgiye götürecek soruları nașil formule edeceğini ve bilgiyi nerede arayacağını, belli bir intiyacı en iyi şekilde karşılayacak bilgi kaynaklarını ve bunları bulmak için bir taramayı nasıl formule edeceğini bilir.

Göstergeleri:

- Bilgiye intiyacı olduğunu bilir.

- Tam ve doğru bilginin karar vermedeki önemini bilir.

- Bilgi ihtiyacına göre sorular formüle eder.

- Potansiyel bilgi kaynaklarını (bilgi kaynağı türlerini) belirler.

- Bilgiyi bulmak için başarılı stratejiler geliştirir ve bunları uygular. 
Standart 2: Bilgi okuryazarı ögrenci, bilgivi eleştirel olarak değerlendirir: Bilgi okuryazarı öğrenci, niteliğine karar vermek için bilgiyi dikkatle değerlendirir. Doğruluk, güvenirlik, ilgilitik, tamlık ve tarafsızlık gibi geleneksel değerlendirme kriterlerini bilir ve uygular. Bunun sonucunda, belli bir ihtiyacı kar\$̧ılamak için belli bir bilgi kaynağını kullanmanın uygun olup olmayacağına karar verebilir.

Göstergeleri:

- Bilgi kaynaklarının doğruluk, ilgililik ve kapsamını değerlendirir.

- Gerçekler, görüşler ve düşünceleri birbirlerinden ayırır.

- Hatalı ve yanlış yönlendiren bilgiyi belirler.

- Eldeki probleme uygun bilgiyi seçer.

Standart 3: Bilgi okuryazan ögrenci, bilgivi doğru ve yaraticl şekilde kullanır: Bilgi okuryazarı bilgiyi etkin şekilde yönetir. Karar vermede, problem çözmede, eleştirel düşünmede ve yaratıcı ifadelerde kullanmak amacıyla çeşitli formatlarda ve türde bilgi kaynaklarından elde ettiği bilgiyi birleştirir, sentezini yapar ve düzenler. Bilgiyi çok çeşitli amaçlarla, çeşitli kitlelere hitaben ve çeşitli formatlarda iletebilir.

Göstergeleri:

- Bilgiyi bir anlam ifade edecek ve başkalarına iletilebilecek şekilde düzenler.

- Mevcut bilgisiyle yeni elde ettiği bilgiyi birleştirir.

- Bilgiyi eleştirel düşünme ve problem çözme amaçlı kullanır.

- Bilgiyi hitap edeceği grubun ihtiyaçlarına uygun düzey ve formatlarda iletir.

\section{Bağımsız Öğrenme Standartlanı}

Standart 4: Bilgi okuryazan öğrenci, ilgi alanlarna yönelik bilgiyi takip eder: Öğrenci bilgi okuryazarlığı becerilerini kişisel ilgi alanlarına yönelik bilgivi takip etmede kullanır. 
Göstergeleri:

- Kişisel olarak ilgi duyduğu konularda (kariyer, sağlık konuları, toplumsal konular, hobiler) bilgi arar. Bilgi problemi çözme becerilerini, kişisel yaşamında almak zorunda olduğu kararlarda da kullanır.

- Kişisel ilgi alaniarıyla ilgili bilgi ürünleri ve problem çözümleri tasarlar, geliştirir.

Standart 5: Bilgi okuryazan ögrenci, her formattaki bilgiye ilgi duyar: Bilgi okuryazarlığı becerilerini yaratıcı ürünlere ulaşmak, onları değerlendirmek ve üretmek için kullanır.

Göstergeleri:

- Kendine yeterli ve kendi kendisini motive eden bir okuyucudur. Kişisel tatmin için bilgi kaynaklarına yönelir.

- Çeşitli formatlarda yaratıcı bir şekilde sunumu yapılmış bilgiden anlam çıkarır. Büyük fikirleri yaşamla ilişkilendirir.

- Çeşitli formatlarda yaratıcı ürünler geliştirir. Fikirlerini ve duygularını en etkin şekilde aktarmak için uygun ortamı seçer ve kullanır.

Standart 6: Bilgi okuryazan öğrenci, bilgi arama ve bilgisini artırma aşamalarında mükemmelliğe gayret eder: Bilgi okuryazarlığł prensiplerini başkalarının olduğu kadar kendisinin bilgi süreçleri ve ürünlerini değerlendirmede de kullanır. Kendi oluşturduğu bilgi ürünlerine karşı sürekli eleştirel bir bakış açısı sergiler. Değişen bilginin ışığında çalışmalarını yeniden gözden geçırir ve geliştirir.

Göstergeleri:

- Kişisel bilgi arama aşamalarının ve bilgi ürünlerinin niteliğini değerlendirir. Bunu yaparken başkalarından gelen geri bildirimlerden de yararlanır.

- Kendi kendisine edindiği bilgiyi güncel tutmaya çalışır.

Sosyal Sorumluluk Standartlar

Standart 7: Bilgi okuryazan ögrenci, demokratik bir toplum için bilginin öneminin farkındadır: Bilgiye ulaşımın, bir demokrasinin fonksiyonelliği için 
temel olduğunu bilir. Konuları tam anlamıla kavrayabilmek için farklı ve çeşitli görüş açıları, farklı bilimsel ekolleri, kültürel perspektifleri yansıtan bilgi arar. Her tür kaynaktan (değişik formałlardaki) bilgi erişiminde eşitliğin demokratik bir hak olduğunu bilir.

Göstergeleri:

- Farklı kaynaklardan, farkı içeriklerde, farklı görūş ve bakış açılarını yansıtan bilgi arar. Bunun için çok sayıda kaynak kullanır.

- Bilgi erişimde eşitlik kavramına saygı duyar. Ödünç aldığı kaynakları zamanında iade eder, sınırlı kaynaklara erişim konusunda paylaşımcıdır, başkalarının haklarının ve ihtiyaçlarının farkındadır.

Standart 8: Bilgi okuryazan öğrenci, bilgi ve bilgi teknolojisi konularında etik davranıs sergiler: Bilgiye ulaşma, bilgiyi değerlendirme ve bilgiyi kullanma ile ilgili etik kurallara uyar. Demokratik bir toplumda bilgiye erişim eşitliğinin önemini kabul eder, düşünce özgürlüğü prensiplerine ve entellektüel mülkiyet haklarına saygı gösterir. Bu prensipleri her tür ve formattaki (basılı, basilı olmayan) bilgiye uygular.

Göstergeleri:

- Düşünce özgürlüğü prensiplerine saygı duyar. Başkalarını düşüncelerini ifade etme konusunda teşvik eder, grup içinde çalışırken diğerlerinin fikirlerine saygı gösterir, gruptaki herkesin fikrini alır.

- Entellektüel mülkiyet haklarına saygı gösterir. Adil kullanım (fair use) kavramını anlar ve uygular, bilgi hırsızlığından (plagiarism) özenle kaçınır, bilginin iletiminde başkalarının ifadelerini kopyalamak yerine kendi ifadelerini kullanır ve kullandığı her bilgi kaynağına gerektiği şekilde gönderme yapar.

- Bilgi teknolojilerini sorumluluğunu bilerek kullanır. Kabul edilebilir kullanım politikalarına ve kurallara uyar, ekipmanı tahsis edildiği amaç için kullanır ve kullandıktan sonra bulduğu gibi çalışır durumda bırakır.

Standart 9: Bilgi okuryazarı öğrenci, bilgi üretimine katkıda bulunmak için başkalarıyla işbirliği yapar: Burada bilgi problemlerinin tanımlanması, problemlere çözüm aranması ve bu çözümlerin doğru ve yaratıcı bir şekilde iletimi konularında başkalarıyla işbirliği söz konusudur. 
Göstergeleri:

- Bilgiyi başkaları ile paylaşır, fikirleri tartışır, iyi bir dinleyicidir ve gerekli durumlarda kendi fikirlerini değiştirir.

- Başkalarının bilgisine ve fikirlerine saygı gösterir. Görüş açılarını ve ifade şekillerini duymak için başkalarının ne söylediğini dikkatle dinler.

- Bilgi problemlerini tanımlamak ve çözümlerini aramak için başkalarıyla iş̧birliği yapar.

- İşbirliği sonucu üretilen çalışmaların değerlendirmesini yapar ve bu değerlendirmenin bulgularını kendini geliştirmek ve çalışma alışkanlıklarını değiştirmek amacıyla kullanır.

\section{Öğrenciler İçin Hazırlanan Bilgi Okuryazarlığı Programlarının içeriği Ne Olmalıdır?}

Bilgi okuryazarlığı tanımları, bilgi problemi çözme aşamaları ve bilgi okuryazarlığı standartları incelendiğinde, bilgi okuryazarı olmak için gerekli bilgi birikiminin ana hatları başka bir deyişle temel bir bilgi okuryazarlığı eğitim programının içermesi gereken konuların bir listesi ortaya çıkmaktadır (ayrıntılı bilgi için ayrıca bakınız: lannuzzi, Mangrum II ve Strichart, 1999; Gordon, 2000):

- Bilgi erişim araçları, türleri ve kullanımları (kütüphane katalogları, indeksler, abstraktlar, elektronik veri tabanları, Internet erişim araçları www arama motorları, Internet rehberieri, vb.).

- Bilgisayarla tarama ile ilgili kavram ve teknikler (anahtar kelime, Boole işleçleri, kesme işlemi, yakınłık belirteçleri, dil ve tarih sınırlamaları vb.).

- Bilgi kaynaklarının türleri, türlerin özellikleri, kullanımları (birincil-ikincil kaynaklar, danışma kaynakları, Internet kaynakları vb.).

- Kütüphane kullanımı.

- Konu başlıkları, sınıflama sistemleri, sınıflama ve yer numaraları nosyonları. 
- Internet araçları, kullanımları, kullanım kuralları (e-posta, ftp, www, net etiket).

- Bilgi kaynaklarının değerlendirilmesi (değerlendirme ölçütleri ve bunların farklı türlere -web kaynakları gibi- uygulanması).

- Özet çıkartma, yorum ve sentez yapma.

- Görsel bilgiyi yorumlayabilme (tablolar, grafikler vb.).

- Sözlü sunum yaprna.

- Yazılı sunum yaprna.

- Bibliyografya ve not kartları hazırlama.

- Gönderme, alıntı yapma, dip not kullanma (ilgili kurallar ve standartlar).

- Bibliyografya hazırlarna (ilgili kurallar ve standartlar).

- Telif hakları ile ilgili yasal düzenlemeler.

Bu listeye eklemeler yapmak her zaman için olasıdır. Burada önemli olan söz konusu bilginin küçük yaşta henüz ilköğretim aşamasındayken öğrençlere düzeylerine uygun olarak aktarılmaya başlanmasıdır. Program için önerilen tüm konuların her düzey için uygun olduğu söylenemez. Ne miktarda bilginin, hangi düzeyde ve ne şekilde öğrencilere aktarılacağı, üzerinde özenle çalışılması gereken bir konudur. Bu noktada kütüphanecilerle eğitimcilerin işbirliği kaçınılmazdır.

Bu tür programlar geliştirilirken bilgi okuryazarlığı programına alınacak öğrencilerin bilgisayar okuryazarı olup olmadıkları da göz önüne alınmalıdır. Bilgi okuryazarlığı bilgisayar okuryazarlığını gerektirdiğinden bu konuda bir eksiklik söz konusu ise önçelikle bu eksikliğin giderilmesi için önlemler alınmalıdır.

\section{Bilgi Okuryazarlığı Becerilerinin Kazandırılmasında Okul Kütüphanelerinin ve Okui Kütüphanecilerinin Rolü}

Bilgi okuryazarlığına dayanan yaşam boyu öğrenimin temeli okul kütüphanelerinde atılır. Zaman içinde okul kütüphaneleri sadece kitap koleksiyonları 
içeren yerler olmaktan çıkıp teknoloji bakımından zengin öğrenim ortamları haline gelirken, okul kütüphanecileri de sadece bilgi sağlama fonksiyonlarını aşıp bugün artık öğrenim süreçiyle de yakından ilgilenir hale gelmiştir (AASL/AECT, 1998, s. 1).

Okul programı ile bütünleşmiş bir okul kütüphanesi ve okul kütüphanecisi, öğrencilerin bilgi okuryazarlığı becerilerini kazanmalanı için gerekli temel unsurlardır (ALA, 2000). Bilgi kaynakları kadar kullanıcıların bilgi ihtiyaçları konusunda da uzman olan kütüphaneciler, okul eğitim programı içinde önemli bir rol üstlenirler (AASL/AECT, 1998, s. 3). Eğitim programını yeterli kaynak, personel ve hem öğrencileri hem de öğretmenleri bağımsız bilgi kullanıcıları haline getirecek bilgi okuryazarlığı programları ile desteklemek üstlendikleri temel sorumiuluklar arasındadır.

Çağdaş eğitim teorisi, öğrenciyi aktif bir bilgi kullanıcısı olarak tanımlar. Aktif bilgi kullanıcısı olacak öğrencilere yardımcı olmanın yolu öğrenci merkezli kütüphane yaklaşımından geçer. Kütüphanenin temel unsuru olan okul kütüphanecisi, öğrencilerin içinde bulunduğumuz çağa uyumunu kolaylaştırmak için öğretmenler, idareciler ve diğer kişilerle ortaklaşa çalışır (AASL/AECT, 1998, s. 2-3) ve bilgi okuryazarlığı eğitim programları geliştirir.

Bilgi okuryazarlığı eğitim programı içinde ele alınan/alınabilecek konular, kütüphanecilerin uzmanlık alanına giren konulardır. Dolayısıyla, bu konuları içeren bilgi okuryazarlığı programlarını hazırlamak da okul kütüphanecilerinin sorumluluk alanına girmektedir. Bir şekilde hemen her tür kütüphanede kul* lanıcı eğitim programlarının parçası olan bu konularda iyi planlanmış ve kapsamlı bir programın her okulda okul kütüphanecileri tarafından geliştirilmesi ve uygulanması gerekmektedir. Bilgi okuryazarlığı eğitim paketleri okul kütüphanecileri tarafından eğitimcilerle işbirliği içinde hazırlanmalıdır. Eğitimcilerle işbirliği sağlanamazsa kütüphaneciler tarafından verilecek eğitim için gerekli olan altyapının sağlanması ve kazandırılan beceriler için uyguiama şansı yaratılması neredeyse olanaksız hale gelir. Örneğin, bilgi okuryazarlığı için temel olarak niteleyebileceğimiz özetleme, sentez yapma, eleştirel düşünme, grup çalışması becerileri eğitimcilerin katkılarıyla eğitim programı içinde kazandırılabilecek becerilerdir. 
Önemli olan bir diğer nokta da bilginin öğrencilerin düzeylerine uygun aktarılabilmesidir. Bu noktada birbirlerinden oldukça büyük farklılıklar gösteren değişik yaş grubundaki öğrenciler için farklı çalışmalar yapma gereği ortaya çıkmaktadır. Hazırlanacak programların öğrencilerin dil ve kavramsal becerilerine uygun olması için özellikle Türkçe öğretmenleri ve sınıf öğretmenleriyle işbirliği önem kazanmaktadır. Gerekli bilgi aktarımından sonra öğrencilerin edindikleri bilgi ve becerileri kullanabilecekleri fırsatlar yaratmak da önemlidir. Bunun için okulda yaratılabilecek en iyi fırsatlar öğrencilere verilecek ödevler ve projelerdir. Öğrencilerin bir ödev veya proje hazırlamak için bilgi okuryazarlığ becerilerine gereks inimleri vardır. Bu becerileri kullandırmaya yönelik ödev ve proje konularının saptanması yine eğitimcilerle kütüphanecilerin işbirliği yapmalarını gerektiren bir başka alan olarak karşımıza çıkmaktadır

Kütüphanecilerin sorumlulukları bilgi okuryazarlığı ile ilgili eğitim programları düzenlemekle bitmemektedir. Söz konusu eğitim programlarının değerlendirilmesi için bir takım değerlendirme ölçütleri geliştirilmesi ve ölçütler çerçevesinde programların sık sık gözden geçirilmesi ve gerekli değişikliklerin yapılması da gereklidir. Okul kütüphanecilerinden ayrıca, dikkatle seçilmiş, ihtiyaçlara uygun, yaşam boyu öğrenmeyi destekleyecek bir kütüphane koleksiyonu oluşturmaları; bu amaçla kullanıcı gereksinimlerini takip etmeleri; her formattaki bilgiye erişimi sağlamaları; öğrencilerin okumaya ilgisini artıracak çalışmalar yapmaları; bilgi bilim alanındaki gelişmeleri izlemeleri; gelişmelere paralel olarak en kısa sürede bilgi okuryazarlığı eğitim paketinde değişiklikler yapmaları (eğitim intiyacı duyulan alanlarda zaman içinde değişiklikler olması kaçınılmazdır); bilgi okuryazarhı̆ı eğitimi alanındaki çalışmaları ve gelişmeleri takip etmeleri ve elde edilen bilgiler ışığında programlarını geliştirmeleri; eğitim-öğretim alanındaki gelişmeleri takip etmeleri; sözü edilen tüm bu alanlarda bilgilerini güncel tutmaları; diğer kütüphaneler ve bilgi merkezleri ile işbirliği yoluyla kütüphane koleksiyonu dışından bilgi sağlama işlemlerini gerçekjeştirmeleri; bilgi teknolojilerini eğitimde kullanmak isteyen öğretmenlere yardımcı olmaları da beklenmelidir. 


\section{Sonuç}

Bilgiyi bulma ve kullanma becerisi olarak tanımianan bilgi okuryazarlığı, yaşam boyu öğrenimin temel taşıdır. Yaşam boyu öğrenimin temeli okulda atılmalıdır. İlk ve ortaöğretim düzeylerinde gerçekleştirilecek bir bilgi okuryazarlığı programı, içinde yaşadığımız çağda gereksinim duyulan insan profiline uygun bireyler yetiştirilmesini sağlayacaktır. Bilgi okuryazarlığı becerilerinin ilk ve ortaöğretim dönemlerinde kazandırı/ması eğitim hayatına devam etmeyecek bireyler açısından büyük önem taşırken eğitimine devam edecek bireylerin başarılarını da olumlu yönde etkileyecektir. İlk ve ortaöğretim düzeylerine uygun bilgi okuryazarlığı programları hazırlama sorumluluğu okul kütüphanecilerine aittir. Programların başarısı ise öğretmenler ve eğitimciler ile yapılacak işbirliğine bağlıdır.

Sonuçta denilebilir ki, bilgi becerileriyle donanmış bir nesil yetiştirme sorumluluğu başta okul kütüphanecileri olmak üzere kütüphanecilerin ve eğitimcilerin omuzlarındadır.

\section{Kaynakça}

AASL/AECT (American Association of School Librarians \& Association for Educational Communications and Technology). (1998). Information literacy standards for student learning. Chicago: American Library Association.

ACRL (Association of College and Research Libraries). (2000). Information Literacy Competency Standards for Higher Education. ACRL. [Çevrimiçi]. Elektronik adres: http//www.ala.org/acrl/ilstandardlo.html [14 Ekim 2001].

ALA (American Library Association). (1989). Presidential Committee on Information Literacy. Association of College and Reserach Libraries. [Çevrimiçi]. Elektronik adres: http//www.ala.org/acrl/nili/lilit1st.html [14 Mart 2001].

ALA (American Library Association). (2000). Information literacy: a position paper on information problem solving. ALA. [Çevrimiçi]. Elektronik adres: http//www.ala.org/aasl/positions/PS_infolit.html [19 Şubat 2000]. 
Bilişim Teknolojileri ve Politikalan Özel intisas Komisyonu raporu. (2001). (Sekizinci Beş Yıllık Kalkınma Planı Yayın No. DPT: 2560-ÖiK 576). Ankara: DPT.

Eisenberg, M. B. \& Berkowitz, R. E. (1992). Information problem-solving: the big six skills approach. School Library Media Activities Monthly. 8(5), 27$29,37,42$.

Gordon, C. (2000). Information literacy in action. Glasgow. European Council of International Scholls.

Grassian, E. (1997). Information literacy competencies-selected items \& efforts. National Information Literacy Institute. [Çevrimiçi]. Elektronik adres: http//www.ala.org/acrl/nili/ilcompt.html [12 Ocak 2000].

Gürdal, O. (2000). Yaşam boyu öğrenme etkinliği: Enformasyon okuryazarıı̆ı. Türk Kütüphaneciliğı. 14(2): 176-187.

Iannuzzi, P. (1999). Information literacy on the WWW. Florida International University Libraries. [Çevrimiçi]. Elektronik adres: http//www.fiu.edu/ - library/ili/iliweb.html [12. 1. 2000].

lannuzzi, P., Mangrum II, C. T. \& Strichart, S. S. (1999). Teaching information literacy skills. Boston: Allyn and Bacon.

The Information literacy model elaborated. (2000). CTAP (California Technology Assistance Project). [Çevrimiçi]. Elektronik adres: http//ctap.tcoe.k12.ca.us/ctap/Info.Lit/Strategies.htm] [21.1 2000].

Kavuncu, E. (2001). Özel ilköğretim okul kütüphanelerinde kullanıcı eğitim programlarının geliştirilmesi. Yayımlanmamış Bilim Uzmanlığı tezi. Hacettepe Üniversitesi. Ankara.

SCANS (1991). What work requires of schools: a SCANS report for America 2000. The Secretary's Commission on Achieving Necessary Skills, U. S. Department of Labor. [Çevrimiçi]. Elektronik adres: http//www.uni.edu/ darrow/trames/scans.htm! [10.3. 2001]. 
Spitzer, K. L., Eisenberg, M. B. \& Lowe, C. A. (1998). Information literacy: essential skills for the information age. Syracuse, N.Y: ERIC Clearinghouse on Information and Technology. (IR-104), Syracuse University.

TÜSIAD (1999). Türkiye'de mesleki ve teknik egitimin yeniden yapllandrriması. Türk Sanayicileri ve İ̧̧adamları Derneği. (Rapor No: TY/184/1999). [Ģevrimiçi]. Elektronik adres: http//www.tusiad.org/turkish/rapor/mesleki/mesleki02-1.pdf. [14. 10. 2001].

Yalvaç, M. (2001). 21. Yüzyılda enformasyon profesyonellerinin eğitim ve öğretıminde enformasyon okuryazarlığı standartları. Türk Kütüphanecilig̈i. 15(2): 136-149. 